\title{
Mera chimaera: the Reformed and Conformist Ecclesiology of John Prideaux (1578-1650)
}

\section{I: The Oxford Act of 1633}

The Christian Church lay at the heart of Early Stuart theological debate. ${ }^{1}$ On $6^{\text {th }}$ July 1633 , there was a dramatic encounter between two rival ecclesiologies in the Oxford Divinity School. One party to this confrontation, Peter Heylyn, has been the focus of significant study by Anthony Milton. ${ }^{2}$ The other party, John Prideaux, has not. ${ }^{3}$ This is surprising, given Prideaux's strategic position within the Church, and his formidable theological reputation. It is the aim of this article to address that gap in the scholarship, focussing particularly on Prideaux's views on the nature, authority and polity of the Church. Given his lasting predominance within Oxford's Divinity Faculty, Prideaux's voice is not one that should go unheard, in any analysis of the Early Stuart Church.

In the summer of 1633, Peter Heylyn intended to crown his academic career, by taking his doctorate at the annual Oxford degree ceremony, or "Act". The last task he had to perform was to defend three theological theses on the Saturday preceding the Act. Normally, an incepting Doctor had most to fear from his Opponents, who were appointed by the University to challenge his theses. But, on this occasion, Heylyn could expect as much trouble from the man moderating the disputation: John Prideaux. Rector of Exeter College since 1612, Regius Professor of Divinity since 1615, with an international scholarly reputation and a network of aristocratic connections, Prideaux was a grandee of Reformed orthodoxy. He was also famously irascible, and he had already crossed swords with Heylyn over the Church, at a disputation in $1627 .{ }^{4}$

Between that earlier altercation, and the 1633 Act, Prideaux's position in Oxford had weakened considerably. He had opposed Laud's election as Chancellor in 1630, supporting Philip Herbert, Fourth Earl of Pembroke, instead. Laud had triumphed and Prideaux was subjected to a campaign of hostile attention thereafter, a campaign recorded in Laud's account of his chancellorship. A fortnight after his election, Laud complained to the Vice-Chancellor's deputy, John Tolson, about a sermon preached by a member of Prideaux's College; the sermon had allegedly been critical of bodily reverence in worship, a reverence enjoined by Canon XVIII. ${ }^{5}$ A few months later, Laud told Prideaux that a question Prideaux had sanctioned, at that year's Act, had displeased the King; he warned the Regius to take more care in future. ${ }^{6}$ A year later, Laud instructed the Vice-Chancellor, William Smith, to admonish Prideaux for failing to deliver the statutory number of lectures. ${ }^{7}$

This last intervention crowned an uncomfortable few months for Prideaux. Early that summer, some young and indiscreet Oxford clergy had delivered sermons accusing the Church's leadership of Arminianism. ${ }^{8}$ The Vice-Chancellor had attempted to discipline them, but they had appealed, via the Proctors, to Congregation. The committee formed to try the case had then let the offending preachers off. Prideaux had been a leading member of that committee. ${ }^{9}$ Smith wrote to the King, complaining that Prideaux's committee had usurped his jurisdiction, and refused to punish factious preachers. This made the maintenance of discipline within the University impossible. ${ }^{10}$ The King decided to investigate the matter himself, hearing the case in Woodstock Palace on 23 August 1631. He expelled the offensive preachers from the University, and dismissed the Proctors who had accepted their appeal. ${ }^{11}$

For his involvement, Prideaux was sentenced to receive, in the presence of the King and the Lords of the Council, "a public and sharp reprehension" for his "misgovernance and countenancing the factious parties". ${ }^{12}$ This was alarming enough; but the King had also remarked that he thought it was 
Prideaux who most deserved to lose his place. Charles only spared him because of his long service as Professor, and Laud's intercession on Prideaux's behalf. One contemporary account suggests that Philip Herbert may also have had something to do with this clemency. ${ }^{13}$ Certainly, Herbert was soon demonstrating his support for Prideaux; sending two of his sons to study at Exeter College in 1632, and a third in $1635 .^{14}$

If Heylyn assumed that Prideaux would have been sufficiently chastened to pull his punches during the Act, he was wrong. And, given that the two men had already clashed over their ecclesiology, Heylyn's choice of theses was provocative: "The Church has authority to determine controversies of faith", "The Church has authority to interpret the Scriptures" and "The Church has authority to decree rites and ceremonies."

As Anthony Milton has indicated, "It is impossible to know precisely what transpired at the 1633 Act." ${ }^{15}$ Peter Heylyn published one account of it, as an appendix to his Examen Historicum. ${ }^{16} \mathrm{He}$ suggests that Prideaux opened the disputation, by asserting that Heylyn's theses did not represent the public doctrine of the Church. To justify this claim, Prideaux allegedly read out a version of Article $\mathrm{XX}$, in which the phrase "The Church hath power to decree rites or ceremonies, and authority in controversies of faith" was missing. Heylyn noticed that Prideaux "had read that article out of the Harmony of Confessions, publish't in Geneva, Anno. 1612;"17 so he dispatched a friend to buy a more accurate edition of the Articles, which he then read out, much to the Professor's chagrin.

Heylyn's account is questionable. It is true that, like several Elizabethan editions of the Articles, the Corpus et Syntagma Confessionum, which had been published in Geneva in 1612, did not contain the opening phrase of Article XX. ${ }^{18}$ But Prideaux was clearly aware of the disputed status of these words, ${ }^{19}$ and it is unlikely that he would make such an egregious mistake about the Articles on the most important day of the academic year. He would, after all, have been told about Heylyn's theses in advance; so they cannot have taken him by surprise. Furthermore, Prideaux's own account of the disputation makes no reference to this exchange:

These questions I approved when they were brought unto me, \& wished the Beadle that brought them to carry them to the Congregation to be allowed according to custom, conceiving them to be especially bent according to the meaning of the Article cited, against Papal usurpations \& puritanical innovations. ${ }^{20}$

Prideaux's account is hardly objective; but it was written within weeks of the disputation, whereas Heylyn's account did not appear until 1659. Laud received a copy of Prideaux's version of events on 22 August $1633,{ }^{21}$ and it appears to have been circulated among Prideaux's allies at the time. ${ }^{22}$ By contrast, Heylyn only wrote his 1659 account, to discredit Prideaux's version of events, when it was published by Sir William Sanderson in a pamphlet hostile to Heylyn. ${ }^{23}$

If Heylyn invented Prideaux's omission of Article XX's opening clause, then he probably intended to smear Prideaux as a Puritan sympathiser. In his Star-Chamber speech at the censure of Bastwick, Burton and Prynne in June 1637, Laud claimed that Puritan libellers had accused him and his allies of intruding the clause into the Articles. Quite the contrary, Laud replied, the clause had been illicitly removed from some editions of the Articles by the Puritans themselves. ${ }^{24}$ Heylyn cited Laud's speech at length in the Cyprianus Anglicus.

The reason Prideaux wrote an account of Heylyn's disputation, was that an informant had denounced him to the King, for making derogatory remarks about the Church and stirring up opposition to the royal prohibition on the public discussion of predestination. Charles asked Laud to 
communicate these accusations to Prideaux, who responded with his own account of the debate. Prideaux believed that the informant had been Heylyn. ${ }^{25}$ Heylyn denied it; ${ }^{26}$ but such behaviour was certainly not out of character. In 1632, Heylyn laid information against his Dean at Westminster, John Williams, who had been one of Prideaux's allies in the attempt to stop Laud becoming Oxford's Chancellor. ${ }^{27}$

The first element of the accusation against Prideaux was that he had been dismissive of ecclesiastical authority: calling the Church a "mere chimaera" and asserting that the Church "neither teaches nor determines" anything. ${ }^{28}$ The second element was that he had made these remarks, in the presence of the Queen's Roman Catholic Almoner, Jacques Le Noël du Perron. The third element was that, when one of Heylyn's Opponents had mentioned the subject of predestination, Prideaux "brake into a great $\&$ long discourse that his mouth was shut by authority, else he would maintain the truth contra omnes qui sunt in vivis [against all those who are alive], which fetched a great hum from the country ministers that were there." 29

Prideaux's reply to these accusations was characteristically robust. To the first, he wrote, "These passages imperfectly catched at by the Informer were no positions of mine, for I detest them as they are laid for impious and ridiculous; but oppositions according to my place, for the further clearing of the truth, to which the Respondent [Heylyn] was to give satisfaction." ${ }^{30}$ That answer, Prideaux thought, should be sufficient to silence any criticism of what he had said as moderator. That said, Prideaux did not deny that he had spoken the phrases alleged against him, and he offered justifications for each remark. Prideaux thought the presence of the Queen's Almoner an irrelevance, but suggested Perron had left after getting bored with Heylyn's argument. On the charge that he had spoken at length about predestination, in defiance of the King's 1628 proclamation; Prideaux replied that he had only touched on the point briefly, and that, "in obedience to authority," he had then prevented the Opponents from pursuing the question any further. If there had been any reaction from the audience, Prideaux remarked, he had not noticed. The only audience involvement he could recall was a hiss, when Heylyn asserted that neither the King nor Parliament were part of the Church. Prideaux ended his response to the accusations with a formal Protestation: he was a loyal son of the Church of England; he had always adhered to her doctrine and discipline, defending it against Papists and Puritans alike, and maintaining the prelacy of bishops as iure divino with more zeal than others who had been better rewarded for doing so. ${ }^{31}$

Prideaux's answer to the charges was apparently accepted. Laud mentions no investigation analogous to that of $1631,{ }^{32}$ and Heylyn indicates that he was not summoned to a meeting about it, though he was serving as one of the King's Chaplains in Ordinary at the time. ${ }^{33}$ That said, the question of the Church's authority remained a live one within the University. In 1634, the ViceChancellor, Brian Duppa, had an old sermon by Francis Mason, The authority of the Church in making Canons and constitutions concerning things indifferent, reprinted. ${ }^{34}$ In 1636, the University Press issued the first Latin edition of the Thirty-nine Articles printed since the days of Elizabeth I, and it included the contested opening phrase of Article XX. Finally, on 10 July 1637, Prideaux chose to give his Vesperial Lecture on "The authority of the Church in matters of the faith."

The 1633 confrontation between Prideaux and Heylyn testifies to the aversion felt by a senior Reformed theologian, to the ideas being propounded by the more audacious apologists for the Laudian style of divinity. In order to understand the roots of that aversion, it is necessary to examine Prideaux's extensive corpus of ecclesiological writings with closer attention than they have hitherto received.

\section{Prideaux on the Nature of the Church}


For Prideaux, the doctrine of the Church was inextricably bound up with the doctrine of election. Charles Prior's aspiration "to shift the focus of our understanding of religious conflict away from Arminianism and Laudianism, and toward the problem of ecclesiology," therefore reflects a sense of theological disjunction, which Early Stuart theologians would not have understood. In Prideaux's mind, the rejection of Arminianism was the precondition for orthodox ecclesiology. In his Fasciculus of 1649, Prideaux makes that link clear:

From the mass of sin God called out, on account of his infinite mercy, those whom he wanted, which assembly of the called is named the Church. 2. The Church is indeed the fixed number of the elect predestined by God's eternal decree, not out of foreseen faith, or works, but out of his mere good pleasure, that they should be made like to his Son, and that, called, justified, and sanctified in this way, they should obtain eternal glory. ${ }^{35}$

Since election defines the Church, the Church is necessarily invisible: "It is not to be discerned by pomp, or external splendour, which appear to the eyes, but from the internal union with Christ through faith, communion with neighbours through charity, \& agreement with the Word of God as to doctrine. ${ }^{36}$ The Church is therefore an object of faith, Prideaux insists, not of sight. ${ }^{37}$ As Anthony Milton has pointed out, writers such as Laud and Montagu downplayed the idea that the Church is, in any significant respect, invisible. ${ }^{38}$ In fact, the Church's perpetual visibility was a focus of Heylyn's 1627 disputations. Prideaux's decision to make the Church's invisibility a central motif in his ecclesiology represented a conscious reaffirmation of the orthodox Reformed position, in the face of Laudian novelty. ${ }^{39}$

That said, Prideaux did not believe that the Church was completely invisible. That would indeed have turned it into the "mere chimaera" he was accused of having made it. Individual congregations are visible, and what identifies them as Churches is their public profession of the Word, and their participation in the Sacraments. ${ }^{40}$ Where Word and Sacrament are present, Prideaux maintains, the Church is present; where they are not, the Church is absent. ${ }^{41}$ Prideaux rejects the suggestion that holiness of life, or love of the brethren, might be considered marks of the Church. They are rather the fruit of the Church's ministry. ${ }^{42}$ The same is true of ecclesiastical discipline. Discipline is not essential to the being of a Church, any more than order is essential to an army, or a hem to a garment; discipline perfects the Church, but it does not constitute the Church. ${ }^{43}$

Prideaux's rejection of both holiness and discipline as essential marks of the Church, sets his ecclesiology against that of separatists such as John Robinson (1576-1625). ${ }^{44}$ But his denial that discipline was a mark of the Church also distinguishes him from those Reformed theologians, such as Bucer and Beza, who made it so, and places him in greater continuity with the ecclesiology of Bullinger, Gualter and Musculus. ${ }^{45}$

For Prideaux, it is the invisible, rather than the visible Church, that is the object of the accolades given to the Church in the New Testament. When applied to the visible Church, he suggests, such accolades are aspirations, describing not what the Church is, but what the Church should be. ${ }^{46}$ Likewise, the creedal attributes "One, Holy Catholic and Apostolic," apply in an unqualified sense only to the invisible Church. The invisible Church may be one in its head, its doctrine and its succession; but there are as many visible Churches, as there are Christian congregations. And it is the Church as a whole that is indefectible, not any of these congregations, ${ }^{47}$ for "All particular churches are subject to defects and mutations." 48 
Since election defines the Church, the reprobate are not members, for "they have no communion with Christ." 49 Such false brethren "are in the Church, but not of the Church;" because "it is one thing to dwell among the members of the Church, another to be a member." ${ }^{50}$ The reprobate are reckoned members, on account of their profession; but, like Judas Iscariot, they are members only by "physical mingling, not spiritual conjunction;" "51 so their presence does not compromise the Church's elect character. The Church tolerates the presence of the reprobate within each Particular Church, for "The Church must bear those whom she cannot discern; and lament what she cannot amend: she must not make a rent in the coat that is seemless, it is reserved for the Angels only, at the last day, between the sheep and goats to make a separation." 52

The claim that the visible Church is inevitably both mixed and fallible undergirds Prideaux's rejoinder to the Roman Catholic claim that the Protestant Church had not existed before Luther. Heylyn accused Prideaux of answering this accusation exclusively by reference to the separatist congregations of medieval Christianity. As Milton has shown, this is untrue. ${ }^{53}$ Prideaux insisted that Reformation "does not erect a new Church, but correct a corrupt one." "54 The Church can be distinguished from the Popery that infected it; and that Church was the same, in essence, as the Protestant Church now is. ${ }^{55}$ Protestants can therefore trace their lineage back to the medieval Church with confidence. As Prideaux remarked, in a sermon before James I, "First, let them convince us, that our Church is new and essentially different from that of our predecessors before Luther, and we shall cast about to frame her a genealogy accordingly."

The mixed nature of the visible Church also enabled Prideaux to discern the Church, even under Roman Catholicism. As he underlined, "Not every corruption overturns the Church, but fundamental and total." ${ }^{\text {"T }}$ The Galatian Church was a Church, though corrupted by Judaism; the Corinthian Church was a Church, even though the Corinthians denied the resurrection; ${ }^{.8}$ and the Roman Church remains a Church, despite her manifest heresy, tyranny and idolatry. Prideaux's position, here, explains the support he offered to Joseph Hall, Bishop of Exeter and Visitor of Exeter College, when Hall was pilloried for suggesting that Rome was a true Church. ${ }^{59}$ In a letter which Hall subsequently published, Prideaux told him that "as often as this hath come in question in our public disputes, we determine here no otherwise than your Lordship;" that is to say, "in respect of the common truths yet professed among the Papists they may, they ought to be termed a true visible Church, in opposition to Jews, Turks and Pagans who directly deny the foundation, howsoever their Antichristian additions make them no better than the Synagogue of Satan." 60

Since visible Churches are inevitably mixed, Prideaux believed, separatism is without excuse. ${ }^{61} \mathrm{He}$ drew a sharp distinction between the schismatic tendencies of some contemporary Protestants, and the godly zeal that had inspired the English Reformation. The Church of England's break with Rome was undertaken, he underlined, "not so much by a local separation, as a necessary renunciation, not of the good she [Rome] hath, but of the poison she hath added." "orderly by the magistrate, authorized by God in that behalf;" 63 and the Church's public institutions can only be altered by legitimate authority. Furthermore, he pointed out, "our refraining, rather than separation from Rome's community, was for known and convinced abominations, of prodigious tyranny, manifest heresy, open idolatry." ${ }^{44}$ The same cannot be said by those who object to the polity of the English Church, because "The refusal of conformity brings no man to the stake, it stops only in some courses, some dangerous private spirits, from wrangling about circumstances, to unite all against the common adversary." 65

\section{Prideaux on the Authority of the Church}


Prideaux addressed the issue of Church authority head on, in his Act Lecture of 1637 . He took as his question: "Whether the Church has any authority to determine controversies of faith among her own," $" 66$ and he began by defining his terms. The Church, Prideaux says, can be considered as triumphant in heaven, or militant in earth. This question clearly pertains only to the Church militant, since there are no controversies in heaven. The Church militant may then be considered generally, as including all believers at all times; or specifically, as restrained to one commonwealth (republica). Prideaux focuses on the latter.

In the Church of a given commonwealth, Prideaux remarks, "(as has been observed most acutely by a Reverend Theologian of ours), the very same men, as regarding things temporal, constitute the commonwealth; as they are referred to spiritual things, assume the name and nature of the Church."67 The theologian Prideaux has in mind here is Richard Hooker. Hooker wrote, in Book VIII of his $O f$ The Laws of Ecclesiastical Polity: "When we oppose the Church therefore and the Commonwealth in a Christian society, we mean by the Commonwealth that society with relation unto all the public affairs thereof.... By the Church, the same society with only reference unto the matter of true religion." ${ }^{68}$ Book VIII of the Laws had not been published, when Prideaux composed his 1637 lecture; but a copy was available in the Bodleian Library, and James Ussher, who was well known to Prideaux, ${ }^{69}$ and who eventually masterminded its first publication in 1648 , had two more. ${ }^{70} \mathrm{By}$ embracing Hooker's position, that the religious and political polities were simply different expressions of the same community, ${ }^{71}$ Prideaux distanced himself from Heylyn's position, which Prideaux felt had excluded the King and Parliament from the Church.

To understand the nature of ecclesiastical authority, Prideaux argues, it is necessary to distinguish between different types of authority; and, in particular, between "the authority of majesty, and of service."72 The sovereign authority "of majesty," admits no earthly appeal; but from the subordinate and ministerial authority "of service," an appeal may be made. ${ }^{73}$ The Church's authority is of this latter and lesser sort. Prideaux then underlines that "It is one thing to determine controversies of faith, another to fashion new articles of faith; in the former, the Church introduces nothing new, but proffers the same deposit that she has received, acting more as witness than judge. Nor does she arbitrarily impose the sense of a controverted Scripture, but expounds [it], according to the reliable means of interpretation." ${ }^{74}$ So the Church may have authority to expound the Scriptures, but the Church cannot promulgate new doctrine. Even so, Prideaux argues that the Church must have a means of resolving religious controversies that arise within her, and he asserts, echoing the opinion he maintained during the 1633 Act, that the divinely sanctioned means of resolving ecclesiastical conflict is a legitimately constituted synod. ${ }^{75}$

Prideaux derives this position from Scripture, and specifically from Matthew 18. There, Prideaux notes, Christ establishes the Church as the ultimate authority for resolving disputes between Christians, and he imposes excommunication as the penalty for those who ignore that authority. These dominical statements demonstrate, Prideaux contends, that every Particular Church has the authority to settle the religious controversies that arise within it. And this is confirmed elsewhere in the New Testament: Ephesians 4:11-14 makes the Church the guardian of the Christian faith, and Hebrews 13:17 instructs Christians to be obedient to their pastors.

Prideaux's choice of this last verse is significant. The anti-Calvinist writer, Samuel Hoard had taken the same verse as his text, a few months before, during a sermon preached at Laud's Metropolitical Visitation at Chelmsford. Hoard used it to argue for a considerably more hierarchical and hieratic understanding of ecclesiastical authority than Prideaux's. For Hoard, ecclesiastical authority effectively meant Episcopal authority: "by Church I mean the Church's pilots, who sit at the stern, and are by their office to guide the ship of the Church through the sea of this world." ${ }^{\text {76 }}$ Hoard also 
underlined that the Apostles and, by extension, the bishops, did not exercise their authority "only when they sat in the Council together, but when they were asunder also."77 There was little place for either synods or the Laity in Hoard's vision of Church authority. Hoard's sermon was preached on 1 March 1637, and received its imprimatur on $28 \mathrm{March}$, the day before Hoard received a Prebend at St Paul's. His views were, in other words, both recently published, and approved by authority.

Prideaux, however, had no truck with them. Acts 15, he thought, makes it clear that the Apostolic Church settled religious controversies in a synod of bishops and pastors. The Jerusalem Council determined the controversy over the observance of the Jewish Law, and promulgated a decree that was observed by all the faithful; Prideaux insisted that "the practice of the Apostles in composing controversies of faith can be and should be most safely complied with by their successors." 78 And the Ecumenical Councils demonstrate that this has been the constant practice of the Church. ${ }^{79}$

The Church's authority to determine controversies is also established by Article XX, Prideaux points out, and he quotes the disputed opening phrase. ${ }^{80}$ Some object, he notes, that this phrase does not appear in several older Latin and English editions. ${ }^{81}$ Prideaux underlines, however, that "Even if these were added, (and whether that is the case, let those discern whom it interests), it suffices to us, that those things which are derived by consequence contain the sacred doctrine (to which we subscribe); namely that the Church is so to determine controversies, that it decree nothing contrary to, or beyond the Scriptures; or impose anything new, as necessarily believed." 82 Given his remarks here, it seems unlikely that he would have made an issue of the disputed phrases, in his exchange with Heylyn. It is clear, however, that Prideaux's reading of Article XX, unlike Heylyn's, emphasises the limits, as much as the extent, of ecclesiastical authority

Having asserted the authority of clerical synods, Prideaux then raises a possible objection, based on the Hookerian view of the relationship between Church and Commonwealth. It could be argued, he suggests, that the consent of the people is also required for the resolution of ecclesiastical controversies. ${ }^{83}$ Prideaux responds by suggesting that these two kinds of assent are not actually in conflict. There are, he indicates, two kinds of determination in religious controversies: the "authentic" determination and the determination "of recognition." The former belongs to God alone, and represents the actual resolution of the question; the latter belongs to human beings, and consists in their acknowledgement of God's ruling. ${ }^{84}$

Within this human kind of determination, there is then a threefold judgement: the judgement of discretion, which belongs to all believers; the judgement of direction, which belongs to pastors; and the judgement of jurisdiction which Prideaux ascribes to prelates (praelatorum). ${ }^{85}$ For Prideaux, in other words, the determination of a religious controversy begins with God exhibiting his "authentic" sentence within his Word. The prelates' task is to make this sentence known, and restrain those who reject it. The pastors' task is to arouse the lazy and the ignorant. The task of the flock is then to embrace the sentence of God that is legitimately promulgated to them by His ministers, when they recognise the voice of the Supreme Pastor within it. ${ }^{86}$ In other words, bishops, clergy and laity all have a place in the Church's resolution of religious disputes.

However, since Christian ministers can err, Prideaux underlines, the laity must test their ministers' teaching against the Scriptures, so as to assure their consciences that their pastors are acting sincerely. Unlike beasts, who simply do what they are told; human beings must exercise their judgement, satisfying themselves that what they have been told is in accord with the knowledge that comes from God. This is what Prideaux calls the judgement of discretion, and since its purpose is to satisfy the conscience of the believer and enable them to embrace what they have been told, this judgement cannot be imposed on anyone else. 
If a believer's discretion suggests that what has been propounded by ecclesiastical authority is mistaken, Prideaux argues, "it will be a mark of Christian modesty, to be more diffident about private perception, than about the company of reverend prelates." ${ }^{, 87}$ Furthermore, he underlines, "Even if manifest prevarication or partisanship is detected; schism must not be considered immediately, but there must rather be participation in what has been accepted; toleration of what cannot be changed; and, finally, hope and prayer, until God, in his own time, restores to wholeness, what has been bent out of shape, or weakened, through legitimate authority and proper means." ${ }^{\prime 8}$ Laudian sympathisers would not have welcomed the suggestion that "manifest prevarication or partisanship" might have tainted the exercise of ecclesiastical authority during the 1630s. And Prideaux's remarks certainly give voice to contemporary Reformed anxieties about the Church's direction of travel. But he was also counselling perseverance, amongst those who were tempted to forsake the Church, whether by fleeing abroad, or by joining separatist communities in England; and lending his support, instead, to those voices within the Reformed theological community that were urging compromise and forbearance. ${ }^{89}$ The Reformed grandee was urging his allies to hold the line.

\section{Prideaux on the Polity of the Church}

In the Protestation he sent to Laud, in 1633, Prideaux claimed

That as I believe the Catholic Church in my creed, so I reverence the Church of England (wherein I have had my baptism \& whole breeding) as a most eminent member of it. To the doctrine and discipline of this Church I have hitherto often subscribed \& by God's grace constantly adhered, \& resolve by the same assistance according to my ability (under his Majesty's protection) faithfully to maintain against Papists, Puritans or any other that shall oppose it. ${ }^{90}$

This profession of unwavering loyalty to the established polity of the English Church is borne out by Prideaux's writings. In Ephesus Backsliding, the first sermon that Prideaux published, he rebuked the Puritan zealots who attacked the polity of the English Church: "Beloved brethren, parity is not purity; nor the wisest preaching, the wrangling about ceremonies." 91 He also denounced the "fanatical spirits of our days... who, upon dislike of our discipline, and some ceremonies they like not, retire themselves to conventicles from their natural mother." 92 Prideaux's support for episcopacy and the Prayer Book, and his hostility to Puritanism, would remain recurrent themes in his writing.

In his Inaugural Lecture for the new Doctors, at the 1624 Act, Prideaux took as his topic ministerial vocation. He underlined that a legitimate vocation was necessary to the exercise of Christian ministry, ${ }^{93}$ for, without vocation, "it is hazardous to preach even the truest things." ${ }^{94}$ For this reason, he argues, the Church of England prudently follows the Apostolic pattern, by retaining the laying on of hands, as well as requiring that bishops be ordained by two or three other bishops, and that presbyters or deacons be ordained by a bishop. ${ }^{95}$ Some Roman Catholic writers have questioned the legitimacy of the Church's bishops; but, as Prideaux asks, "Are they not consecrated by legitimate bishops \& with appropriate solemnity?" 96 He underlines, at this point, that he is only seeking to defend Protestant orders in England; the defence of the Transmarine Churches he leaves to others. ${ }^{97}$ For, although he is in no doubt that Luther, Calvin and the other continental Reformers had legitimate vocations; he maintains that "With ours, however, the conspicuous succession shines forth more brightly." "98 Prideaux's defence of English orders is thus unashamedly Episcopalian; and this is consistent with the Jacobean tendency to emphasize the local Episcopal succession observed by Anthony Milton. ${ }^{99}$ 
Prideaux's confidence in English Church polity extended to the Church's liturgy. He refers approvingly to the Prayer Book in his sermons, quoting from its Collects, ${ }^{100}$ and responses,${ }^{101}$ noting the patterns of its lectionary, ${ }^{102}$ and commending its choice of Canticle. ${ }^{103}$ By contrast, Prideaux condemns the Puritans for "their extemporary babbling, and brawling against our set forms of prayer;" "104 noting that their tendency to vent such ramblings in Church, squeezed out what he considered were "better forms, than their best premeditations can afford us." 105 Prideaux stands as a counter-example to Alec Ryrie's observation that there was relatively little interest in the official liturgy prior to $1640 .{ }^{106} \mathrm{He}$ particularly valued the Prayer Book calendar, finding edification in the observance of Advent, ${ }^{107}$ and of the solemnities that mark Lent and Eastertide. ${ }^{108}$ Prideaux also refers in the highest terms to the Church's festivals. ${ }^{109}$ His enthusiasm for the liturgical year was manifested in the Directions for the Bursar and Butler, which were drawn up during his time as Rector of Exeter, and which ensured that the Exonian diet constantly reflected the Church's festivals and seasons. ${ }^{110}$ Well before the liturgical order of the Church of England came under threat, in other words, Prideaux was exhibiting his enthusiasm for the Prayer Book calendar.

Even so, it was the 1640's that elicited Prideaux's most substantial defences of English Church polity. These works were all conceived after Prideaux was made Bishop of Worcester, in November 1641, so they carried the added gravity of his Episcopal authority. Prideaux wrote two substantial defences of Episcopacy: one in a letter to his former tutee, John Robartes (later Earl of Radnor), that was published at the Restoration, ${ }^{111}$ the other in the Fasciculus controversiarum (1649). He also defended the English liturgy in the Fasciculus, as he did, with a more pastoral focus, in the

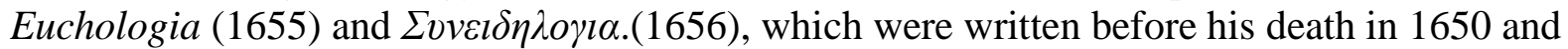
posthumously published. Given this record, Prideaux deserves to take his place among the noted Episcopalian apologists of the Interregnum. And, when seen in that context, he reinforces Milton's point, that 1640s "Anglicanism" was not as "moderate" as has sometimes been assumed. ${ }^{112}$ Given the unyielding defences of the ecclesiastical status quo that Prideaux offers in these works, is little surprise that the 1641 Lords' Subcommittee on Religious Innovation, on which he sat, gave little ground to Puritan concerns. ${ }^{113}$

When Prideaux discusses episcopacy in the Fasciculus, he asks "Whether, by the institution of Christ, or the Apostles, the episcopate is an order, or degree, distinct from the presbyterate, and superior to it?" 114 Prideaux's phrasing here is studiedly imprecise; suggesting, as it does, that a distinction of order, and a distinction of degree, were more or less synonymous. Prideaux was well aware that they were not, as he made clear in his letter to Robartes. There, he underlined that bishops and presbyters "are of the same order, but not of [the same] dignity in the same order, as the more precise scholastics state. 2. Whence, from the identity of order they preach the Word and minister the sacraments with equal right: but on account of the disparate dignity in the same order, with regard to ecclesiastical orderliness, these superiors exercise certain acts of government, which are not fitting for the others except in case of necessity." 115 As Milton has indicated, the issue of whether bishops and presbyters differed by order, or degree, was a point of significant contention among the supporters of episcopacy; so Prideaux's decision to gloss over this issue was perhaps a tactical one, aimed at maintaining a common Episcopalian front. ${ }^{116}$

Prideaux notes that that the terms "bishop," "priest" and "deacon," as used in the New Testament, denote different kinds of ministry. And, since I Corinthians 14:40 establishes the principle that decency and order ( $\varepsilon v \sigma \chi \eta \mu$ oviav and $\varepsilon v \tau \alpha \xi 1 \alpha v)$ should be observed within the Church, ${ }^{117}$ these different kinds of ministry must be properly coordinated. Prideaux underlines that he is not attempting to justify Episcopal titles, prerogatives or incomes; he is merely asserting that bishops have authority over their presbyters. As he puts it, bishops "may justly claim jurisdiction over 
presbyters, from the institution of Christ, or the practice of the Apostles." 118 Modern zealots may deny this, but the most celebrated Churches of Christendom have affirmed it for 1500 years.

Prideaux then sets out the arguments for his position. The Old Testament furnishes an analogical authority for the tripartite ministry, he suggests, in the distinction between the High Priest, the Priests and the Levites. His interpretation of the Old Testament follows that of James Ussher, in a work to which Prideaux elsewhere refers. ${ }^{119}$ Prideaux argues that the distinction between bishop and presbyter is further confirmed under the Gospel. A collation of Matthew 10 and Luke 10 shows that Christ placed the Apostles above, and ordained them before, the other Seventy Disciples: bishops are the Apostles' successors; presbyters succeeded the Seventy. The primacy of bishops over their presbyters is therefore a dominical institution. ${ }^{120}$ The bishops' Apostolic succession can be demonstrated, Prideaux believes, from Acts 1:20, which refers to the Apostleship that Matthias took over from Judas Iscariot as his "episcopate" ( $\varepsilon \pi 1 \sigma \kappa o \pi \eta v)$. Prideaux also notes the solemnity, with which Matthias was elevated from the ranks of the Seventy; a solemnity which would not have been necessary, had there been no substantial difference between the two orders. ${ }^{121}$

For Prideaux, it is a principle of orthodoxy that "The Apostolic practice in those things that should be done (like [Apostolic] precepts in those things that should be believed), is to be taken as a divine canon to the whole Church for the conservation of common order and discipline." 122 It is clear, he thinks, from Acts 13:2 that Paul and Barnabas were solemnly ordained for their Apostolic work. Acts 14:23 confirms that they then ordained presbyters in the cities of Asia Minor. I Timothy 5:22 and Titus 1:5 demonstrate that Timothy and Titus were later ordained to this Episcopal role as well. Prideaux gives a little more detail about his understanding of Apostolic practice in the Epistola. He notes that Titus is charged, in Titus 1:5, with putting the Church in order and ordaining presbyters in every town. So Titus held both the right of ecclesiastical oversight and the power to ordain. Timothy is told in I Timothy 1:3 to instruct people not to teach a different doctrine. So Timothy had theological authority over his presbyters' preaching. Timothy is also instructed, in I Timothy 5:19, not to accept any accusation against a presbyter without witnesses. So Timothy enjoyed canonical jurisdiction to try his presbyters as well. ${ }^{123}$

For Prideaux, all this is incontrovertible evidence that Episcopal oversight was practiced within the Apostolic Church. He draws the same conclusion from the seven letters to the Churches of Asia found in Revelation 2-4. He identifies the angels, to whom the letters were addressed, as the bishops of the Asian Churches; and argues that, since the angels are told how to regulate the life and teaching of these Churches, they clearly exercised Episcopal jurisdiction. ${ }^{124}$ Prideaux further notes that James Ussher had recently demonstrated that this Apostolic practice extended into the post-Apostolic era. ${ }^{125}$ In fact, Episcopal government continued uninterrupted for 1500 years: the succession of bishops was the Church's bulwark against heresy, and the Early Church Fathers condemned any who, like Aerius, refused to accept it. ${ }^{126}$ The continental Reformers generally endorsed Episcopal government as well, at least as it was practiced in England. In their patterns of superintendency, Prideaux argues, the Lutherans "differ either little or nothing from our side." 27 The theologians of Zurich, for their part, have always been supportive of Episcopacy, as can be seen, he suggests, in the writings of Bullinger and Gualter. Even some of the theologians of Geneva have praised it. ${ }^{128}$ The Church of England has, therefore, no reason to be ashamed of her polity.

Prideaux then turns to the objections which have been raised by "innovators." The first is derived from the dominical prohibition on disciples exercising dominion over one another, found in Matthew 20:25-26 and its parallels. Prideaux responds by deploying the distinction between coercive and ministerial authority which he used in his 1637 lecture. Christ forbad the Apostles from exercising coercive dominion over their brethren, but not the paternal and directive dominion of service. ${ }^{129}$ To 
the objection that the terms bishop and presbyters are sometimes used in Scripture for the same person (e.g. in Acts 20:17 \& 28), Prideaux explains that presbyters retain their presbyterate when they become bishops, simply adding their prelature to it. ${ }^{130}$ And, in answer to the claim that the Apostles received miraculous guidance from the Holy Spirit, and therefore had no successors; Prideaux answers that Apostles received both the extraordinary Apostolic calling, and the ordinary calling of Episcopal oversight: the latter, but not the former, was transmitted to the bishops. ${ }^{131}$

Prideaux notes the criticism that an Episcopal polity promotes Popery, by opening a way to papal tyranny and by undermining the discipline of Reformed Churches abroad. Neither claim is true, he thinks. The Bible underlines that Jesus is the only shepherd and guardian of Christian souls (I Peter 2:25), and that He is always present with His Church (Matthew 28:20); so there is no need for one bishop to serve as His deputy. Quite the contrary: the Apostles are referred to as sitting on equal thrones (Matthew 19:28) and as receiving equal authority (John 20:23). Rightly conceived, therefore, an Episcopal model of government is actually a counterweight to Papal tyranny.

As to the Protestant Churches abroad, Prideaux opines, "there is no reason for them to excite such a destructive conflagration about our orthodox bishops, for we are not inwardly condemning their discipline, because we prefer ours, as an institution of the Saviour and the Apostles, and more consistent with the practice of the whole Catholic Church until now." 132 Once again, Prideaux is a little less guarded in the Epistola. There he writes, of the other Protestant Churches:

They have the distinct offices of Episcopate and Presbyterate, even if they are not administered by different persons. And just as the supreme power of the sword, which is exercised amongst us monarchically, among them aristocratically; so the Episcopal jurisdiction of the keys, which is most appropriately adapted to the condition of the Commonwealth, is perhaps more helpfully administered with them by many rather than by one. ${ }^{133}$

The Superintendents, Antistes and Moderators, that are accepted in the Transmarine Churches, are analogous to bishops, and more fitting for their condition. ${ }^{134}$ For that reason, "nothing is lacking to them, which is fitting to sacred discipline; nor avails us, that we should less charitably acknowledge and embrace them as brothers and fellow-ministers in the Lord." 135

Prideaux's argument here is a bold one. The best trodden path in Early Seventeenth Century ecclesiology was to defend the orders of the continental Reformed Churches on the grounds of necessity: such Churches could not enjoy Episcopacy, at least for the time being, so presbyteral ordination was acceptable faute de mieux. ${ }^{136}$ But Prideaux seems here to suggest that the decision to abandon Episcopal government might be a fitting one, where the civil polity was not monarchical. Prideaux's position is similar to the way Arthur McGrade describes Richard Hooker's attitude to Episcopacy; namely, that it is "divinely instituted or approved, historically well tested, yet not immutably fixed as the only possible, legitimate form of Church government." 137 Hooker's thinking found echoes in John King and John Bridges. ${ }^{138}$ If Laud felt that Joseph Hall was giving away too much ground on Episcopacy, he would have had even more difficulty with Prideaux's view. ${ }^{139}$

In his discussion of the English liturgy, in the Fasciculus, Prideaux began by defending the value of set liturgies in general. The disadvantages of not adopting a set form of prayer are obvious, he suggests. Allowing extemporary prayers opens the way for Enthusiasts to cause constant distraction during public worship. It makes worshippers uncertain about whether they were going to be able to say "Amen." It deprives the ignorant of the religious instruction which set liturgies provide. It results in crude prayers being proposed to the Church. It induces torpor in the congregation, who have 
nothing to do but depend upon the meandering efforts of the speaker. Above all, it offends against the principles of $\varepsilon v \sigma \chi \eta \mu o v i \alpha \nu$ and $\varepsilon v \tau \alpha \xi 1 \alpha \nu$ that have been prescribed to the Church as a general canon. ${ }^{140}$

Set liturgies do not, Prideaux contends, compromise the intercession of the Spirit, for the Spirit assists all who pray, whether in set forms or not. ${ }^{141}$ Nor can it be argued that set liturgies impede preaching: "The commandments of God are not to be opposed, but composed, such that they do not impede each other by turns, but promote each other. Those liturgies are therefore to be approved, which render sermons more effective, not those which exclude or impede them."142 That said, Prideaux is critical of "Those thematic declaimers who, by importunate garrulity, drive away public prayers from the assemblies of the faithful, such that they only are heard and honoured." 143 Prayer and preaching go hand in hand in Prideaux's model of liturgical order: for, as he underlined at the consecration of Exeter College Chapel in 1624, "public prayers and sermons (for aught I find) never trespassed one upon another, till the itching humours of some men of late, would needs set them together by the ears."

Turning to the English liturgy Prideaux insists that the Prayer Book is perfectly consonant with Scripture. In the first place, it was put together by sincere doctors, who were either eminent martyrs or confessors. He specifically mentions Cranmer, Grindal, Sandys, Taylor, Jewel, Humfrey and Horne. The eye-catching inclusion of the originally anti-vestiarian Laurence Humphrey, and the exclusion of the staunchly vestiarian Matthew Parker, despite the fact that Parker had masterminded the 1559 Prayer Book, was probably another of Prideaux's inclusive gestures in the Fasciculus. ${ }^{144}$ These holy men, Prideaux claimed, had expunged all that deformed the earlier English rites, and assembled everything suitable for worship from ancient Christian liturgies. The Prayer Book expresses all the modes of prayer, from confession to imprecation. ${ }^{145}$ "It collects apt portions of scripture, and texts, that are serviceable to the time, the place and the occasion, as well as popular instruction and edification, and offers with them a brief and easy catechism." 146 The Prayer Book enjoins those bodily gestures most conducive to reverence. ${ }^{147}$ It provides for all areas of the Church's life. ${ }^{148}$ It has received the approbation of many Reformers. ${ }^{149}$

Prideaux considers the objections that have been raised against the Prayer Book, and concedes not a single one. In fact, Prideaux takes an even harder line in the Fasciculus than had the 1641 Lords' Subcommittee, of which he had been part. The Subcommittee contemplated abandoning the Apocrypha; ${ }^{150}$ Prideaux defended it. ${ }^{151}$ They were prepared to consider cutting back on Saints Days, ${ }^{152}$ Prideaux thought they were all justifiable. ${ }^{153}$ They were prepared to consider introducing the Authorized Version for all lections $;{ }^{154}$ Prideaux went out of his way to explain why the older translation did not adversely affect the sense. ${ }^{155}$

The same is true of the one major concession which the Lords' Subcommittee had contemplated, namely abandoning the sign of the cross in Baptism. ${ }^{156}$ Prideaux now defended it: "This is not imposed as necessary, but as indifferent, not as a complement to baptism, but as an earnest of memory, handed on from the ancients, to the Christian soldiery." "157 And, with regard to the other two most controversial ceremonies, Prideaux took quite as conservative view as the Subcommittee. On the surplice, he underlined that this is merely adiaphora and reflects the same concern for decorum and personal distinction that can be seen in the ceremonies of the Old Testament. ${ }^{158}$ On kneeling to receive the Eucharist, Prideaux again insisted that this is again merely adiaphora, and is a gesture expressing the reverence due to such a mystery. ${ }^{159}$

The only point, on which Prideaux allows the latitude in the Fasciculus, that he was prepared to concede in 1641, is Church music. The Subcommittee had enjoined that Church music should be 
more edifying and intelligible; Prideaux concedes that affected music is indeed unhelpful. ${ }^{160}$ However, he underlines that, where the music is appropriate, it is conducive to solemnity and devotion; which is why, in the Old Testament, both vocal and instrumental music were used, and that by divine command. ${ }^{161}$ Prideaux's enthusiasm for Church music is not a late development, either. The manuscript copy of the order of consecration of Exeter College Chapel in 1624 makes clear that both choral and instrumental music played a prominent part in the ceremony. ${ }^{162}$

Prideaux's robust defence of the Church's established polity continued in his posthumously published pastoral works. In the Euchologia, he commends the Prayer Book to his daughters "as fittest for your use, and most complete and warrantable for the grounds it stands upon." $" 163 \mathrm{He}$ endorsed the Prayer Book's use of gesture in worship, and condemned those who objected to it: "It is a plot of Satan to brand due reverence of the body with the scandal of superstition. Bowing at the name of Jesus, standing at the creed, kneeling at the receiving of the Lord's Supper; must be held by some superstitious, and to smell of popery." 164 As he underlines, "That mean must be kept between warrantable ceremonies and superstitious fooleries; that in detesting the one, we prove not profane in the other." 165 For "That which the Apostle requireth, 'Let all things be done decently and in order,' is of a large extent." ${ }^{166}$ Once again, I Corinthians 14:40 is Prideaux’s guiding star.

Prideaux's loyalties are again evident in the $\Sigma v v \varepsilon 1 \delta \eta \lambda \mathrm{o} \gamma 1 \alpha$. Against those who demand a sermon at every service; he insists that reading can beget faith in the hearer without preaching. ${ }^{167}$ Although conceding that the Apocrypha might be replaced with passages from Scripture, at the discretion of the minister, he defends its inclusion in the lectionary, "by reason of the consonancy of that which is read out of them with the canon, the respect by the ancient given unto them, and the instructiveness of style." ${ }^{68} \mathrm{He}$ is also adamant that the Church's appointed festivals are perfectly legitimate: "If we, upon good grounds for extraordinary blessings appoint a day, or more, for prayer, praise and thanksgiving, we have the pattern of the Old Testament, and the practice of our Saviour, who honoured with his presence, and preaching, the feast of the dedication, ordered by the Maccabees."169

Given his support for the established order of the Church, it is no surprise that Prideaux has little time for those Protestants who opposed it. Anti-Puritanism consequently coloured Prideaux's thought, much as did that of his successor as Regius, Robert Sanderson. ${ }^{170}$ In Prideaux's preaching, Puritans are aspiring reformers without warrant of station or calling. ${ }^{171}$ Guided by their misconceived sabbatarianism, Puritans are killjoys who would deprive people of innocent pleasures: "humourous schismatics, that snarl at this and the like festivals, and are come at length to a Jewish niceness, as to deny the dressing of meat upon the Sabbath Day; I say no more, from such the poor may expect poor Christmases." 172 Prideaux's Puritans are afflicted by "peevishness," denouncing all as profane "that sorteth not with their singularity." 173 They are "refractory prescribers to their mother, proscribers of their brethren," ${ }^{174}$ who attack set forms of prayer, and oppose their superiors. ${ }^{175}$ Rather than preaching profitably, Puritans prefer to attack ceremonies they dislike, and denounce faulty ministers, forgetting that "zeal may run without discretion, and do more harm than good." ${ }^{176}$ For Prideaux, the root cause of Puritanism is a "Donatistical humour," 177 and Donatism is one of the four archetypal heresies that had always afflicted the Christian Church. ${ }^{178}$

That said, Prideaux's depiction of Puritanuism was not unrelentingly negative. Peter Lake has underlined the need to attend to the different shades of tone and emphasis within Anti-Puritan polemic $;{ }^{179}$ and Prideaux's vein of Anti-Puritanism had perhaps a little more room for the idea of a moderate Puritan than Sanderson's. ${ }^{180}$ Prideaux observed, on one occasion, that there are many moderate Puritans, who overcome their scruples and resist the lure of separatism: "Divers moderate spirits there remain among us, who perchance approve not all our ceremonies, yet run not to Amsterdam, as holding such a remedy more dangerous than the cause." 181 This acknowledgement 
that there was such a thing as a moderate Puritan may have prompted Prideaux's appeal for forbearance in the 1637 Act lecture. Prideaux also acknowledged that Puritan feeling has been needlessly provoked, by the high-handed behaviour of some senior clergymen. "I pray God the... causeless strangeness, and stateliness of some, so different from the Apostolical humility, to their meaner and weaker brethren, have not made more schismatics, and (as we call them) Puritans, than all the vantages that could be taken, against the sacred order of our Reverend Bishops, or any part of our Church-discipline, or ceremonies." For Prideaux, clerical presumption such as Heylyn demonstrated in the 1633 Act, was clearly as noxious a presence within the Church as Puritanism. Indeed, Prideaux saw them as counterparts. Who will dwell of God's holy hill? Prideaux asked, echoing Psalm 15: "Not those that will set up prelates, to depose princes, or those that maintain a faction, to pluck down prelates: but he that leadeth and uncorrupt life."182

\section{Conclusion}

As Regius Professor at Oxford for twenty-seven years, John Prideaux was an influential theological voice for much of the Early Stuart period. He was a scholar of international reputation, who enjoyed a remarkable network of contacts across the Reformed world. A celebrated Tutor and College Head, he was also in a position to shape the religious loyalties of generations of the British gentry. ${ }^{183}$ Combining an unflagging loyalty to Reformed orthodoxy, with demonstrable enthusiasm for the established polity of the English Church, Prideaux was, to Laudian clergy such as Peter Heylyn, virtually the embodiment of the old theological order. It is no surprise, therefore, that Prideaux was exposed to regular attack, when the Laudians began to stretch their wings.

As Anthony Milton has shown, ecclesiology was a battleground between the Laudians and their theological opponents. It was also, of course, a well-established locus of confrontation between the Reformed Churches as a whole, and Rome. And it later became a battlefield between the supporters and the opponents of the existing polity of the Church of England, when that polity was threatened, and then abolished, during the 1640s. The nature, authority and polity of the Church was consequently a major focus of Prideaux's interest throughout his career.

Prideaux's ecclesiology was inextricably bound up with a Reformed understanding of election. As a result, the invisible Church loomed larger within his writing, than it did among his Laudian contemporaries. Prideaux's conviction that the elect necessarily coexisted with the reprobate, within each Particular Church, gave him sufficient theological latitude to trace the ancestry of Protestantism back to the medieval Church, and, with Joseph Hall, to recognise the true Church even within Roman Catholicism.

Prideaux believed that each Particular Church was entitled to resolve religious disputes between her members, and that the proper means for doing so was in a legitimately constituted synod. Such a synod had the authority to rule on all ecclesiastical controversies, subject always to the overriding norm of scripture. Ecclesiastical authority was thus necessarily ministerial, rather than coercive in nature. The duty of bishops was to exercise discipline over those who ignore the Church's authority. The duty of pastors was to communicate what has the Church has agreed. The duty of each lay person, as a rational being, was to examine the Church's determinations, in the light of Scripture, and to accept them where they were found to be consonant with Scripture. In the event that they were not, forbearance was to be preferred to schism.

When attacked over remarks he made about the Church, during the 1633 Oxford Act, Prideaux claimed that he had always defended the established polity of the English Church, and his writings 
bear that out. He consistently endorsed Episcopacy, as rooted in scripture and consonant with the practice of the Apostolic Church and, consequently, iure divino. But his reverence for Episcopacy did not prevent him accepting that other models of Church government might be better adapted to a non-monarchical Commonwealth.

Prideaux's writings also exhibit his consistent support for the Church of England's established liturgical order. He celebrated the Prayer Book calendar, its lectionary, and its liturgy. He was prepared to accept the limited compromises offered to the Puritan party by the Lords' Subcommittee on Religious Innovation; but he rowed strongly back from them, once the prospect of a settlement receded.

Given Prideaux's fondness for English Church polity, it is no surprise that his writings were marked by a powerful strain of anti-Puritanism. Prideaux recognised, however, that there was such a thing as a moderate Puritan, and he lamented the provocations offered by their exorbitant clerical colleagues. This may explain why, in his 1637 Act lecture, he urged perseverance among those members of the Reformed community, who were tempted to abandon the Church. Prideaux was clearly working to shore up the Reformed front in the face of the Laudian onslaught.

Prideaux's ecclesiology offered a vision of Conformity that was firmly rooted within Reformed orthodoxy, and untainted by Laudian innovations. His presentation of ecclesiastical authority emphasised the limits of the Church's authority, rather than its extent. With its insistence on synodical government, and the role of the laity, in the resolution of ecclesiastical controversy, it undermined the hierarchical claims of polemicists such as Samuel Hoard. Prideaux combined this Counter-Laudian ecclesiology, with a readiness to use his academic offices to oppose the spread of Laudian ideas, and to denounce prominent Laudian clergy as crypto-Papists. This explains why Prideaux, unlike Sanderson, could never sit comfortably within the Caroline regime.

\footnotetext{
${ }^{1}$ Milton, Catholic and Reformed, p 27. Prior, Defining the Jacobean Church, p 19.

${ }^{2}$ Milton, Laudian and royalist polemic

${ }^{3}$ Prideaux may not have been the focus of a dedicated study, but his significance is such that he has certainly not been overlooked. His dogged opposition to the rise of Anti-Calvinism has been traced by Nicholas Tyacke; Sarah Mortimer has underlined his role in the Socinian controversy; Anthony Milton has referred widely to Prideaux's views on the Church. Cf Tyacke, Anti-Calvinists, pp 74, 82, 148-149; Mortimer, Reason and Religion, pp 55-58; Milton, Catholic and Reformed, passim.

${ }_{4}$ Milton, Laudian and royalist polemic, pp 20-21

${ }^{5}$ Wharton (ed), Remains of William Laud, $\mathrm{p} 8$.

${ }^{6}$ Wharton (ed), Remains of William Laud, p 17 Prideaux denied that he had allowed the question as stated. Ibid, p 19.

${ }^{7}$ Wharton (ed), Remains of William Laud, p 30

${ }^{8}$ Tyacke, Anti-Calvinists, p 82.

${ }^{9}$ Richard Hill, a member of Brasenose College, who was clearly implicated in these events, but was absent from Oxford, when the King heard the case, later sent a grovelling letter to Laud, laying the blame for his own involvement squarely at Prideaux's door: 'the example of Dr Prideaux, my father (whom with reverence I am to name) too much ruled within my breast.' Wharton (ed), Remains of William Laud, $\mathrm{p} 49$

${ }^{10}$ Wharton (ed), Remains of William Laud, p 42.

${ }^{11}$ Tyacke, Anti-Calvinists, p 82.

${ }^{12}$ Wharton (ed), Remains of William Laud, p 44.
} 
${ }^{13}$ F.S.Boas (ed.), Diary of Thomas Crosfield, p 56.

${ }^{14}$ Foster (ed.), Alumni Oxonienses 1500-1714, s.v. 'Hon. Charles Herbert'. 'Philip Herbert', 'William Herbert.'

${ }^{15}$ Milton, Laudian and Royalist, p 50

${ }^{16}$ Milton, Laudian and Royalist, pp $21 \& 50$

${ }^{17}$ Heylyn, Examen Historicum, ii, Appendix

${ }^{18}$ Corpus et Syntagma, p130. The Corpus et Syntagma was sometimes referred to, incorrectly, as the Harmony of Confessions: cf Hall (ed.), Harmony of Protestant Confessions of Faith, pp xvii-xix fn *. Heylyn is, however, incorrect when he states that this work used the Edwardian Articles: it was probably drawn from one of the Elizabethan editions in which it was lacking, such as the London editions of 1571 or 1575 . The actual Harmony of Confessions published by Jean-François Salvart in 1581did not refer to an edition of the Thirty-nine Articles, but to excerpts from Jewel's Apology. Salvart, An Harmony of the Confessions, Catalogue of Confessions, iiii.

${ }^{19}$ Prideaux, Viginti-duae, p 358.

${ }^{20}$ Bodl. Rawl MS D353, f 104r.

${ }^{21}$ Wharton (ed), Remains of William Laud, p 64, marginal note.

${ }^{22}$ Heylyn, Examen Historicum, ii, Appendix 3r. This may be the origin of the manuscript copy in the Bodleian.

${ }^{23}$ Sanderson, Post-haste.

${ }^{24}$ Heylyn, Cyprianus Anglicus, p 339.

${ }^{25}$ In Bodl. Rawl MS D353, f 104r-104v, the author of the charges to which Prideaux is responding is identified as Heylyn. The version in Laud's history of his Chancellorship does not make that clear, although it indicates that the informant had offered to avow his charges on oath, if required: Wharton (ed), Remains of William Laud, p 63.

${ }^{26}$ Heylyn, Examen Historicum, ii, Appendix, P2r.

${ }^{27}$ Milton, Laudian and Royalist, p 46. ODNB s.v.. 'John Williams'

${ }^{28}$ Bold. Rawl MS D353, f 104 r. 'Ecclesia est mera chimaera. Ecclesia nil docet nec determinat.'

${ }^{29}$ Bodl. Rawl MS D353, f $104 \mathrm{v}$.

${ }^{30}$ Bodl. Rawl MS D353, f 104 r.

${ }^{31}$ Bodl. Rawl MS D353, f $104 \mathrm{v}$

${ }^{32}$ Wharton (ed), Remains of William Laud, p 64.

${ }^{33}$ Heylyn, Examen Historicum, Appendix, P2 v. Heylyn does mention that 'this business of Dr Prideaux was in agitation' on the Thursday or the Friday of his week in residence as Chaplain. Anthony Milton has taken as indicating that Prideaux was again summoned to Woodstock: Milton, Laudian and Royalist, p 49 n; but the wording is ambiguous.

${ }^{34} O D N B$, s.v. 'John Prideaux.'

${ }^{35}$ John Prideaux, Fasciculus, p 134. 'Ex massa peccati Deus pro infinita sua misericordia, quos voluit, evocavit, qui coetus evocaturum dicitur Ecclesia. 2. Est autem Ecclesia certus electorum numerous per aeternum Dei decretum praedestinatus, non ex praevisa fide, vel operibus, sed ex mero ipsius beneplacito, ut conformes fierent filio ipsius, \& ita evocati, justificatie \& sanctificati, aeternam tandem consequerentur gloriam.'

${ }^{36}$ Prideaux, Fasciculus, p 144. 'Non ex pompa, aut splendore externo est aestimandum, quae patent oculis, sed ex unione interna cum Christo per fidem, \& communion cum proximis per charitatem, \& consensus cum verbo Dei quoad doctrinam.'

${ }^{37}$ Ibid.

${ }^{38}$ Milton Catholic and Reformed, pp289-299.

${ }^{39}$ Milton Catholic and Reformed, pp 278-281.

${ }^{40}$ Prideaux, Viginti-duae, p 141.

41 Ibid.

${ }^{42}$ Prideaux, Fasciculus, p 162.

${ }^{43}$ Prideaux, Ephesus, p 14.

${ }^{44}$ George, John Robinson, p 100.

45 Benedict,Christ's Churches Purely Reformed, pp 214-215.

${ }^{46}$ Prideaux, Viginti-duae, p 129.

${ }^{47}$ Prideaux, Viginti-duae, p 130.

${ }^{48}$ Prideaux, Fasciculus, p 144. 'Particulares omnes ecclesiae defectibus \& mutatonibus sunt subjecta.'

${ }^{49}$ Prideaux, Fasciculus, p 173.

${ }^{50}$ Prideaux, Fasciculus, p 175. 'Sunt in Ecclesia, sed non ex ecclesia; videntur, sed non sunt.... Aliud est inter membra Ecclesiae versari, aliud esse membrum.'

${ }^{51}$ Prideaux, Fasciculus, p 176. 'Commixtione corporali, not conjunction spirituali.'

52 Prideaux, Ephesus Backsliding, pp 10-11.

${ }^{53}$ Milton, Laudian and Royalist, p 21.

${ }^{54}$ Prideaux, Viginti Duae, p 136. 'Non novam erigit Ecclesiam, sed corruptam corrigit.'

${ }^{55}$ Ibid.

56 John Prideaux, Perez-Uzzah, p 12. 
${ }^{57}$ Prideaux, Fasciculus, p 161. 'Non omnis corruptio Ecclesiam evertit, sed fundamentalis \& totalis.'

${ }^{58}$ Ibid.

${ }^{59}$ Milton, Catholic and Reformed, p 142.

${ }^{60}$ John Prideaux's letter, in Hall, Reconciler , pp 94, 92-93.

${ }^{61}$ Prideaux, Ephesus, p 11.

${ }^{62}$ Prideaux, Ephesus, p 12.

${ }^{63}$ Ibid.

${ }^{64}$ Ibid.

${ }^{65}$ Prideaux, Ephesus, p14.

${ }^{66}$ Prideaux, Viginti-duae, p 348. 'Utrum Ecclesia habeat aliquam authoritatem ad controversias fidei inter suos determinandis.'

${ }^{67}$ Prideaux, Viginti-duae, p349. '(Ut acutissime observavit Reverendus e nostris Theologus) iisdem hominess, ut respiciunt temporalia constituent rempublicam; ut referantur ad spiritualia, Ecclesiae nomen et naturam induunt.'

${ }^{68}$ Hooker, McGrade (ed), Laws of Ecclesiastical Polity: Preface, Book I, Book VIII, p 135.

${ }^{69}$ Ford, James Ussher, pp 209 \& 211.

${ }^{70}$ Hooker, Ussher (ed), Of the Laws of Ecclesiastical Polity: the Sixth and Eighth books, 'The several copies compared before publication.'

${ }^{71}$ Brydon, The evolving reputation of Richard Hooker, p 57.

72 Prideaux, Viginti-duae, p 349. 'Authoritatis majestatis \& muneris.'

${ }^{73}$ Ibid.

${ }^{74}$ Ibid. 'Alius esse de fide controversias determinare, aliud fidei novos articulos cudere, Ecclesia hic nil novi infert, sed profert tantum depositum accepit, indicem potius agens, quam iudicem. Nec imponit pro arbitratu sensum scripturae controversae, sed exponit, iuxta indubitata interpretandi media.'

${ }^{75}$ Prideaux, Viginti-duae, p 349. 'Convenit primo, Deum aliqua saltem reliquisse Ecclesiae suae media, ad lites in ea excitatas definiendas \& determinandas. Convenit secundo inter omnes non emotae mentis, canonicam scripturam eousque esse illius determinationis normam, ut nil quod certo in ea contineatur, vel indubitatis consequentis inde deduceatur, praetextu quovis a Christianis rejiciatur. Convenit tetio, ad Episcopis, seu Pastores legitime vocatus, munus explicatndi \& applicandi istam normam ex officio spectare.... Convenit quarto, Ecclesiam universalem, seu Catholicam, controversias non derimere, nisi in suis deputatis, quatenus certo loco, tempore, aut spectabili aliqua synodo legitime congregantur... Ultimo, ut Ecclesia aliqua Particularis in subditos non suos, non cncessam ipsi a Deo usurpet authoritatem.'

${ }^{76}$ Hoard, Church's Authority, p 7.

${ }^{77}$ Hoard, Church's Authority, pp 8-9.

${ }^{78}$ Prideaux, Viginti-duae, p 356 . 'Praxis Apostolorum in componendie fidei controversiis tutissime a posteris ipsorum potest ,et debet observari.'

${ }^{79}$ Prideaux, Viginti-duae, p 357.

${ }^{80}$ Ibid.

${ }^{81}$ Prideaux, Viginti-duae, p 358.

82 Prideaux, Viginti-duae, p 358. 'Utcunque ista fuerint adjecta (qua de re viderint illi quorum interest) nobis sufficit quod exposita per consequential, sacram continent (cui subscripsimus) doctrinam: nempe Ecclesiam sic determinare controversias, ut nil aversus, vel praetor scripturas decernat, vel necessaria creditu, de novo imponat.'

${ }^{83}$ Prideaux, Viginti-duae, p 358.

${ }^{84}$ Prideaux, Viginti-duae, p 358.

${ }^{85}$ Ibid. Prideaux's choice of the word 'praelatorum' is significant. As we shall see, he believes that bishops are indeed prelates, but he also sees prelacy at work in non-Episcopal forms of ecclesiastical discipline.

${ }^{86}$ Ibid.

${ }^{87}$ Ibid. 'Christianae erit modertiae, diffidere potius privatae perspicaciae, quam reverendo praelatorum coetui.'

${ }^{88}$ Ibid. 'Sin manifesta deprehendatur praevaricatio, \& partium stadium; non meditanum statim schism, sed communicandum in receptis; tollerandum quod non tolli potest; $\&$ expectandum demum, et orandum, donec Deus suo tempore quod distortum est, aut laxatum, legitima aliqua authoritate ac debitis mediis, in integrum restituat.'

${ }^{89}$ Webster, Godly Clergy, pp 156-157,165-166, 273-276.

${ }^{90}$ Bodl. Rawl MS D353, f 104v.

${ }^{91}$ Prideaux, Ephesus, pp 27-28.

${ }^{92}$ Prideaux, Ephesus, p 11.

${ }^{93}$ Prideaux, Viginti-duae, p 73.

${ }^{94}$ Ibid. 'Extra vocationem ausus sit vel verissima praedicare.'

${ }^{95}$ Ibid.

${ }^{96}$ Prideaux, Viginti-duae, p 76. 'Nunquid non a legitimis Episcopis \& debita sollennitate consecrati?'

${ }^{97}$ Ibid. 
${ }^{98}$ Ibid. 'Apud nostros autem conspicua magis elucescit successio.'

${ }^{99}$ Milton, Catholic and Reformed, p 462.

${ }^{100}$ Prideaux, Idolatrous Feasting, p 19 \& Prideaux, Great Prophet's Advent, p 1.

${ }^{101}$ Prideaux, Patronage of Angels, p 26.

102 Prideaux, Advent, p1.

${ }^{103}$ Prideaux, Idolatrous, p 20

${ }^{104}$ Prideaux, Hezekiah, p 16.

105 Prideaux, Hezekiah, p 13.

106 Ryrie, Being Protestant, p 318

${ }^{107}$ Prideaux, Free-will offering, p 6.

108 Prideaux, First fruits, p 29.

${ }^{109}$ Prideaux, Idolatrous, p 27.

${ }^{110}$ Exeter College Library, Oxford MS A.IV.II, Directions for the Bursar and Butler.

${ }^{111}$ Prideaux, De Episcopatu

112 Milton, 'Anglicanism and Royalism,' pp 62-63.

${ }^{113}$ Hampton, 'Theological Junto', p 449.

${ }^{114}$ Prideaux, Fasciculus,p 204. 'An ex institutione Christi, aut Apostolorum, episcopatus sit ordo, sive gradus, a presbyteratu distinctus, eoque superior.'

115 John Prideaux, De Episcopatu Epistola (London 1660), p 4. 'Eiusdem ordinis sunt, sed non dignitatis in eodem ordine, ut punctiores statuunt scholastici. 2. Unde ex ordinis identitate pari iure verbum praedicant et sacramenta administrant: sed ob disparem dignitatem in eodem ordine, quoad $\varepsilon v \tau \alpha \xi 1 \alpha \nu$ ecclesiasticam, hi superiors quosdam gubernationis actus exercent, qui aliis nisi in casu necessitates non convenient.'

${ }_{116}$ Milton, Catholic and Reformed, pp 466-470

${ }^{117}$ Francis Mason, following John Calvin, called this verse 'a golden canon or rule whereby all Christian Churches must be ruled,' Mason, Authority, p 4.

${ }^{118}$ Prideaux, Fasciculus, p 204. 'Jurisdictionem in presbyteros ex Christi institutione, aut Apostolorum praxi juste vendicent.'

${ }^{119}$ Ussher, Original of Bishops, pp 52-53.

${ }^{120}$ Prideaux, Fasciculus, p 205.

${ }^{121}$ Prideaux, Fasciculus, p 206.

122 Prideaux, Fasciculus, p 206. 'Praxis Apostolica in agendis, ad totius Ecclesiae $\sigma v v \tau \alpha \xi 1 \alpha \nu$ \& disciplinae conservationem (ut praecepta in credendis) pro canone divino est tenendda.'

${ }^{123}$ Prideaux, Epistola, p 2.

${ }^{124}$ Prideaux, Epistola, p 2.

${ }^{125}$ Prideaux does not cite a specific work, but it is probably Original of Bishops, which was published as part of his Certain Brief Treatises (1641).

${ }^{126}$ Prideaux, Fasciculus, p 208.

${ }^{127}$ Prideaux, Fasciculus, p 209. 'Paum aut nihil a nobis ex parte dissentiunt.'

${ }^{128}$ Prideaux, Fasciculus, p 210.

${ }^{129}$ Prideaux, Fasciculus, p 210.

${ }^{130}$ Prideaux, Fasciculus, p 211.

131 The Apostolic calling was extraordinary, Prideaux suggests, in that it came immediately from Christ, entailed miraculous instruction by the Holy Spirit, and a universal commission. Prideaux, Fasciculus, p 213.

${ }^{132}$ Prideaux, Fasciculus, p 216. 'Non est quod de Episcopis nostris orthodoxis tam funesta exitarent incendia, non enim disiplinam illorum penitus damnamus, quia nostrorum praeferimus, ut Salvatoris \& Apostolorum institutioni, adeoque totius Ecclesiae Catholicae praxi magis consentaneam.'

${ }^{133}$ Prideaux, Epistola, p 8. 'Distincta apud eos habentur Episcopatus \& Presbyteratus official, tametsi a distinctu non administrentur personis. Ut enim summa gladii potestas, quae apud nos monarchice, apud illos aristocratice exercetur: sic et clavium jurisdiction Episcopalis, quae reipublicae conditioni confectissime adaptatur, commodius illis per plures quam per unum forsan administratur.'

${ }^{134}$ Prideaux, Epistola, p 8.

${ }^{135}$ Prideaux, Epistola, p 8. 'Nihil illis deest quod sacrae disciplinae convenit; nec nobis suppetit, quo minus illos per Fratribus \& Symministris in Domino charissimis agnoscimus \& amplectamur.'

136 Milton, Catholic and Reformed, $\mathrm{p} 476$.

${ }^{137}$ Arthur McGrade, 'Richard Hooker on Episcopacy and Bishops, good and bad,' International Journal for the study of the Christian Church 2 (2002), pp 28-46, p 32.

${ }^{138}$ Milton, Catholic and Reformed, p 460.

${ }^{139}$ Cf. Milton, Catholic and Reformed, p 489.

${ }^{140}$ Prideaux, Fasciculus, pp 231-232. 


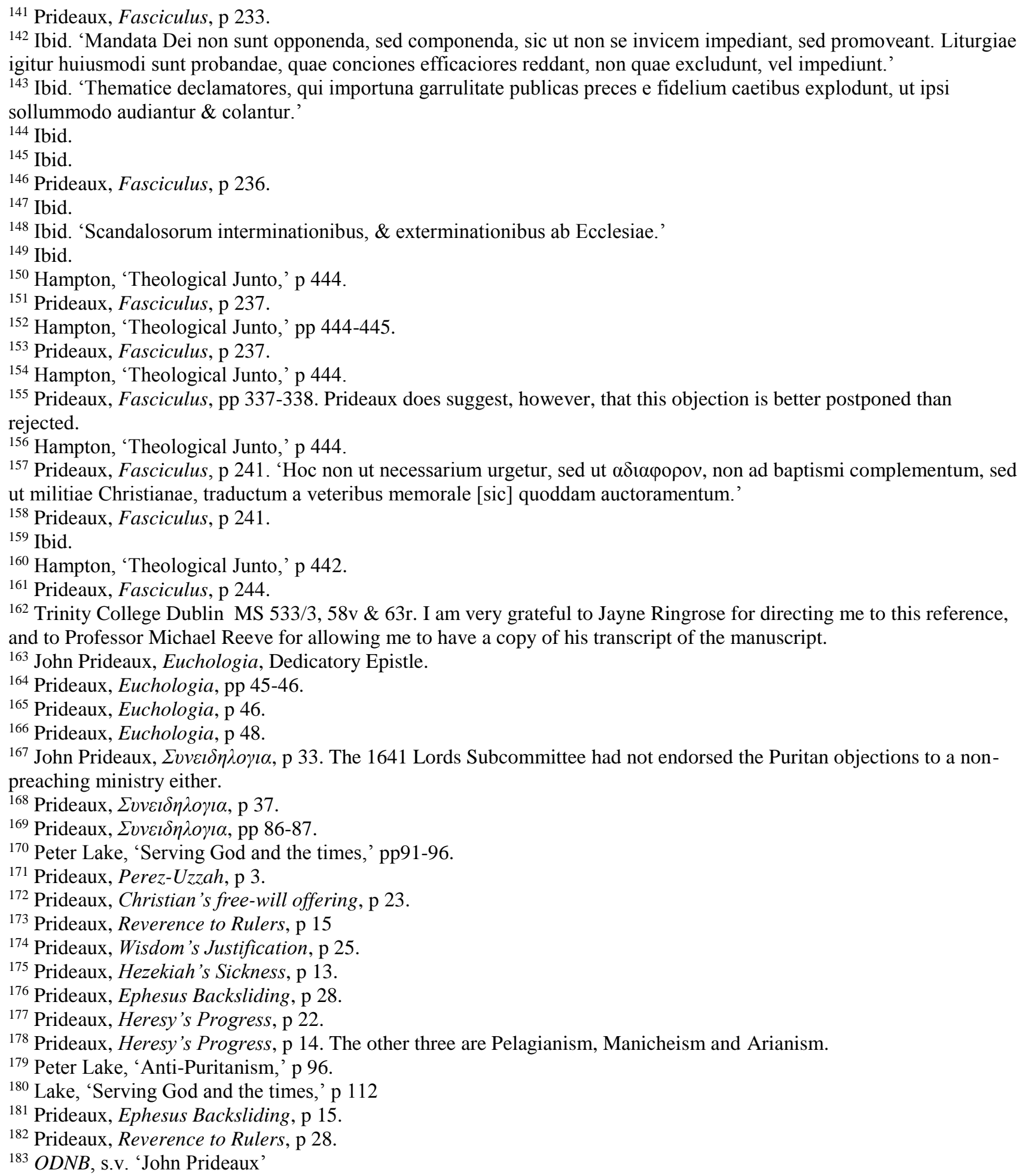

